\title{
Reduction Of Usership In Selected Academic Institutions Ncr Delhi: A Descriptive Study
}

\author{
AbidaDurrany $^{\text {a }}$, Dr. N. Amsaveni ${ }^{\text {b }}$ \\ ${ }^{a}$ Research Scholar, Bharathidasan University \\ ${ }^{\mathbf{b}}$ Assistant Professor, Department Of Library \& Information Science, Bharathidasan University, Tiruchirappalli, Tamil Nadu
}

Article History: Received: 10 November 2020; Revised 12 January 2021 Accepted: 27 January 2021; Published online: 5 April 2021

\begin{abstract}
This study examines the state of university libraries in Delhi, using descriptive research and in-depth interviews with seven central universities in the city. The descriptive research included respondents such as teachers, students, and other library users. The findings identify the challenges that library users' encounter, including the prevalence of existing libraries, traditional facilities and services, and the implementation of new policies. The one-sample t-test results for digital technologies showed $\mathrm{P}>0.05$, indicating that digitization in libraries has an impact.The study's findings clearly indicated that university libraries in NCR Delhi, which are housed within existing college buildings, contain obsolete resources that are randomly arranged, giving students and teachers negative attitudes toward libraries. There are no new collections or proper electronic systems in university libraries, which has created a slew of problems for professors and students who use libraries for study. As a result, the study stresses the value of accepting technical advances that can contribute to greater levels of success
\end{abstract}

Keywords: Education, library usage, technology,digitalization, facilities, services

\section{Introduction}

Educational institutions play a crucial role in society by educating future generations to use the expertise they have gained to perform their roles more effectively. The libraries of these institutions represent a wide range of people, such as students, faculty, administrators and staff with diverse information needs. These libraries gather a range of information sources and provide a variety of resources to support educational, research and learning programs. The importance of libraries in educational institutions is therefore considerable and is also seen as a centre of academic activity [1]. Since the university library is committed to offering excellent tools and facilities, it must build an ongoing dialog with its user group. On the other hand, academic libraries must boost the quality of their services in order to succeed in this volatile competitive environment [2].

Reforms that aim to reform existing practices and/or conventions need imagination that leads to inventions that enhance libraries [3]. Among the many advances in the library, efficient information management [4], digitalization services [5,6] and participation in social activities [7] are at the top of the list! Libraries in general, and universities in particular, are essential stores of human knowledge and information, as well as key facilitators of learning and research, offering a wide range of facilities to meet the needs of users. These developments have the potential to impact students, change their learning experiences, and are critical to the growth of academic institutions $[8,9,10]$. In other words, having suitable academic library spaces that are calm and quiet has a huge impact on improving learning outcomes $[11,12,13,14,15]$. These libraries, however, do not have to be confined to their physical space; the advent of electronic resources has made research easier, quicker, and more efficient [16].

With ongoing efforts to improve productivity and provide higher-quality information and knowledge-based services, the introduction of digital academic tools is unavoidable in many libraries. Adoption of such technological advances has evolved into an important characteristic of active academic libraries. There is a high demand for new libraries and information services in this digital era, which contributes to a higher level of success [17].After all, all modern libraries began as traditional and progressed through transitional phases to reach their current state [18].

\section{Methodology}

Descriptive research design is used in the study to find the reduction of library usage in selected academic institutions of NCR Delhi. Seven academics institutions situated in Delhi were selected for the present study. An analysis was done over the selected respondents to evaluate the frequency of library usage. 


\section{Research Design}

As part of the descriptivestudy conducted within the target region, a survey instrument was employed to gather data in order to gain insights behind the library services provided in the academic institutions in the target region. A total number of 30 respondents were selected and the data was collected in the form of responses. Explored population included Professors, students and other users within the seven selected institutions in Delhi. The following Central Universities situated at Delhi were selected-

1. Delhi University

2. Jawaharlal Nehru University

3. JamiaMiliaIslamia University

4. Indraprastha University

5. J P University, Greater NOIDA

6. Galgotia University, Greater NOIDA

7. Sharda University

This study thus examines the frequency of library usage in the academic institutions situated in Delhi.

\section{Data analysis}

Data obtained were analysed using SPSS (version 20). Inferential statistics associated with the frequency of library usage in the academic institutions situated in Delhi wereanalysed by test. All inferential statistics were achieved at the 95 percent confidence level.

\section{Results}

Despite the fact that several trends emerged from the data collected, the current study focuses on the key topics related to university libraries in Delhi and how current users perceive such academic libraries.

\section{Validity and Reliability of Research Instrument}

The validity of the questionnaire was measured using the Content validity index. Reliability is measured by using the Cronbach's alpha coefficient. In the statistics the test using the Cronbach alpha should be greater than 0.5 , to get the perfect reliability of the questionnaire.

Table 1 Reliability statistics

\begin{tabular}{|l|l|}
\hline \multicolumn{2}{|l|}{ Reliability Statistics } \\
\hline Cronbach's Alpha & N of Items \\
\hline .547 & 72 \\
\hline
\end{tabular}

Table 1 indicates that the alpha value is 0.547 , which is between 0.5 and 0.75 , this means that the reliability of the questionnaire is moderately reliable for analysis [19].

\section{Exploratory Factor Analysis}

Exploratory factor analysis (EFA) is used for calculating the relations between the observed and latent variables whether they are unidentified or undefined. The method progresses in an exploratory way to extract the underlying factors, demonstrating the relations between latent observed variables [20]. The purpose is to come out with the minimum number of factors that will explain the relationship among the observed variables.

Table 2. KMO and Bartlett's Test

\begin{tabular}{|c|c|c|}
\hline \multicolumn{3}{|l|}{ KMO and Bartlett's Test } \\
\hline \multicolumn{2}{|c|}{ Kaiser-Meyer-Olkin Measure of Sampling Adequacy. } & .852 \\
\hline \multirow[t]{3}{*}{ Bartlett's Test of Sphericity } & Approx. Chi-Square & 4597.912 \\
\hline & df & 596 \\
\hline & Sig. & .000 \\
\hline
\end{tabular}


Table 2 shows the Kaiser-Meyer-Olkin measure of sampling adequacy and Bartlett's test of Sphericity. The results inferred the best analysis fit because KMO statistic varies from 0 and 1 . Accepting values greater than 0.5 is recommended by Kaiser. The present value is 0.852 , implying that the model is suitable for acceptance.

\section{Regression analysis}

\section{Purpose and frequency of using the library}

Table 3. One-sample t- test forpurpose and frequency of using the library

\begin{tabular}{|l|c|c|c|}
\hline Variables & t & df & $\begin{array}{c}\text { Sig. } \\
\text { (2-tailed) }\end{array}$ \\
\hline For information related with job in routine work & & .29 & .116 \\
\hline To collect statistical data & 5.233 & .067 \\
\hline To obtain geographical information & 8.425 & 29 & .078 \\
\hline For general reading & 7.453 & 29 & .127 \\
\hline To prepare for class lecture & 5.272 & 29 & .000 \\
\hline To consult laws, rules, reports etc. & 16.155 & 29 & .074 \\
\hline $\begin{array}{l}\text { To keep-up with the current developments in the area of } \\
\text { study }\end{array}$ & 4.232 & 29 & .247 \\
\hline To get information for research work & 9.465 & 29 & .046 \\
\hline How frequently you use the library? & 4.775 & 29 & .321 \\
\hline
\end{tabular}

Table 3 shows t- value for purpose and frequency of using the library. The results showed that $\mathrm{t}$-values with regard to purpose and frequency for using the library showed $P>0.05$ for all the variables except for the usage in preparing for class lecture and for gathering information for research work. This indicates that there is no significant difference in the purpose and frequency for using the library. This argument indicates that weak library collections contribute to user dissatisfaction with libraries [21,22,23,24]. This shows that there has been no development or advancement in libraries that leads to dissatisfaction among users.

Library collection

Table 4. One-sample t- test forlibrary collection

\begin{tabular}{|c|c|c|c|}
\hline Variables & $\mathbf{t}$ & dff & $\begin{array}{l}\text { Sig. } \\
\text { (2-tailed) }\end{array}$ \\
\hline \multicolumn{4}{|l|}{ Books } \\
\hline General Collection & 44.012 & 29 & .000 \\
\hline In your area of specialization & 46.756 & 29 & .000 \\
\hline Reference Books & 41.268 & 29 & .000 \\
\hline Manuscripts & 44.870 & 29 & .000 \\
\hline \multicolumn{4}{|l|}{ Theses/Reports } \\
\hline Theses/Dissertations & 45.639 & 29 & .000 \\
\hline Research /Projects Reports & 46.756 & 29 & .000 \\
\hline Govt. Reports & 39.952 & 29 & .000 \\
\hline Conference /Seminar Proceeding & 46.005 & 29 & .000 \\
\hline
\end{tabular}




\begin{tabular}{|l|c|c|c|}
\hline E-Resources & 48.119 & 29 & .000 \\
\hline Periodicals & 39.140 & 29 & .000 \\
\hline Back Volumes of Periodicals & 60.691 & 29 & .000 \\
\hline Current Periodicals & 34.626 & 29 & .000 \\
\hline Indexing Journals & 47.507 & 29 & .000 \\
\hline Abstracting Journals & & \multicolumn{3}{|c|}{.319} \\
\hline Non-book / E-Resources & 3.417 & 29 & .248 \\
\hline E-Books / E-Journals & 3.135 & 29 & .000 \\
\hline On-Line Databases & 6.364 & 29 & .000 \\
\hline CD-ROM Database & 6.283 & 29 & .000 \\
\hline Maps/Atlases & 5.570 & 29 & .182 \\
\hline Slides & 5.663 & 29 & \\
\hline Micro-films/Micro-fiches & & & \\
\hline Organization of Documents & & & .000 \\
\hline How do you find the arrangement of documents on shelves? & 16.155 & 29 & \\
\hline
\end{tabular}

Table 4 shows t- value for the library collection. The results showed that t-values with regard to library collection showed $P<0.01$ for all the variables except for the E-Resources, where there is no significant difference in the availability of E-Books/E-Journals and On-Line databases.The results thus show the value of establishing electronic tools that make research simpler, faster and more effective. In several libraries, the introduction of digital academic tools is unavoidable, implying that users have embraced the electronic journal world[16,8].

\section{Library services}

Table 5. One-sample t- test forlibrary services

\begin{tabular}{|c|c|c|c|}
\hline Variables & $\mathbf{t}$ & df & $\begin{array}{l}\text { Sig. } \\
\text { (2-tailed) }\end{array}$ \\
\hline CAS & 21.153 & 29 & .000 \\
\hline Circulation & 13.614 & 29 & .000 \\
\hline Current Contents & 14.748 & 29 & .000 \\
\hline Indexing & 13.001 & 29 & .000 \\
\hline Inter Library Loan & 12.479 & 29 & .000 \\
\hline Literature Search & 16.868 & 29 & .000 \\
\hline New Arrivals & 13.320 & 29 & .000 \\
\hline Press Clipping & 15.056 & 29 & .000 \\
\hline Reference & 12.960 & 29 & .000 \\
\hline Reprographic & 12.669 & 29 & .000 \\
\hline SDI & 12.420 & 29 & .000 \\
\hline
\end{tabular}


Table 5 shows t- value for the library services. The results showed that t-values with regard to library services showed $P<0.01$ for all the variables. The results thus infers that a significant service exists in the university libraries. This indicates that technical resources play a vital role in the professional growth of all libraries [25].

\section{Overall administrative aspects}

Table 6. One-sample t- test foroverall administrative aspects

\begin{tabular}{|c|c|c|c|}
\hline Variables & $\mathbf{t}$ & df & $\begin{array}{c}\text { Sig. } \\
\text { tailed) }\end{array}$ \\
\hline $\begin{array}{c}\text { Are you satisfied with number of books issued } \\
\text { and period of loan? }\end{array}$ & 15.703 & 29 & .000 \\
\hline $\begin{array}{l}\text { As a research scholar do you consider that lack } \\
\text { of user's orientation programme in the library } \\
\text { service stands in the way of your research work }\end{array}$ & 26.492 & 29 & .000 \\
\hline $\begin{array}{l}\text { Does the library provide computerized services } \\
\text { to you? }\end{array}$ & 7.954 & 29 & .546 \\
\hline
\end{tabular}

Table 6 shows t- value for overall administrative aspects. The results showed that $t$-values with regard to overall administrative aspects showed $P<0.01$ for all the variables except for the computerized services.Computerization can have a huge effect on users' ability to return to libraries; nevertheless, this service is not accessible in the majority of academic libraries [18].

\section{Modern technology}

Table 7. One-sample t- test formodern technology

\begin{tabular}{|l|c|c|c|}
\hline Variables & t & df & $\begin{array}{c}\text { Sig. } \\
\text { tailed) }\end{array}$ \\
\hline Bibliographic service (On demand) & & & .426 \\
\hline Circulation & 5.265 & 29 & .432 \\
\hline Current Awareness Service & 5.703 & 29 & .425 \\
\hline Current Contents & 5.425 & 29 & .561 \\
\hline List of new arrivals & 4.568 & 29 & .341 \\
\hline Literature Search & 7.265 & 29 & .384 \\
\hline New Arrivals & 6.159 & 29 & .492 \\
\hline On-line service & 6.896 & 29 & .298 \\
\hline Selective Dissemination of Information & 7.954 & 29 & .348 \\
\hline Serial Control & 6.155 & 29 & .356 \\
\hline $\begin{array}{l}\text { Does your library provide on-line searching of } \\
\text { National and International Databases }\end{array}$ & 6.858 & 29 & .314 \\
\hline In-house databases & & & \\
\hline CD-ROM Databases & 5.571 & 29 & .296 \\
\hline Online Databases & & 29 & \\
\hline
\end{tabular}


Table 7 shows t- value for the availability of modern technology. The results showed that t-values with regard to modern technology showed $P>0.05$ for all the variables. The results thus infers that there is no significant difference in the availability of modern technology in the university libraries. This shows that electronic resources have a greater effect than borrowing facilities in today's university libraries[25,10].

\section{SEM Analysis}

In the present study, the Structural Equation Modelling submits the covariance matrix of scale scores to Amos. This technique is a combination of factor analysis and multiple regression analysis, and is used to analyse the structural relationship between measured variables and dormant concepts and gives the goodness of fit based on Analysis of covariance of structure. Current research favours this technique because it evaluates the numerous and unified need in a single analysis.

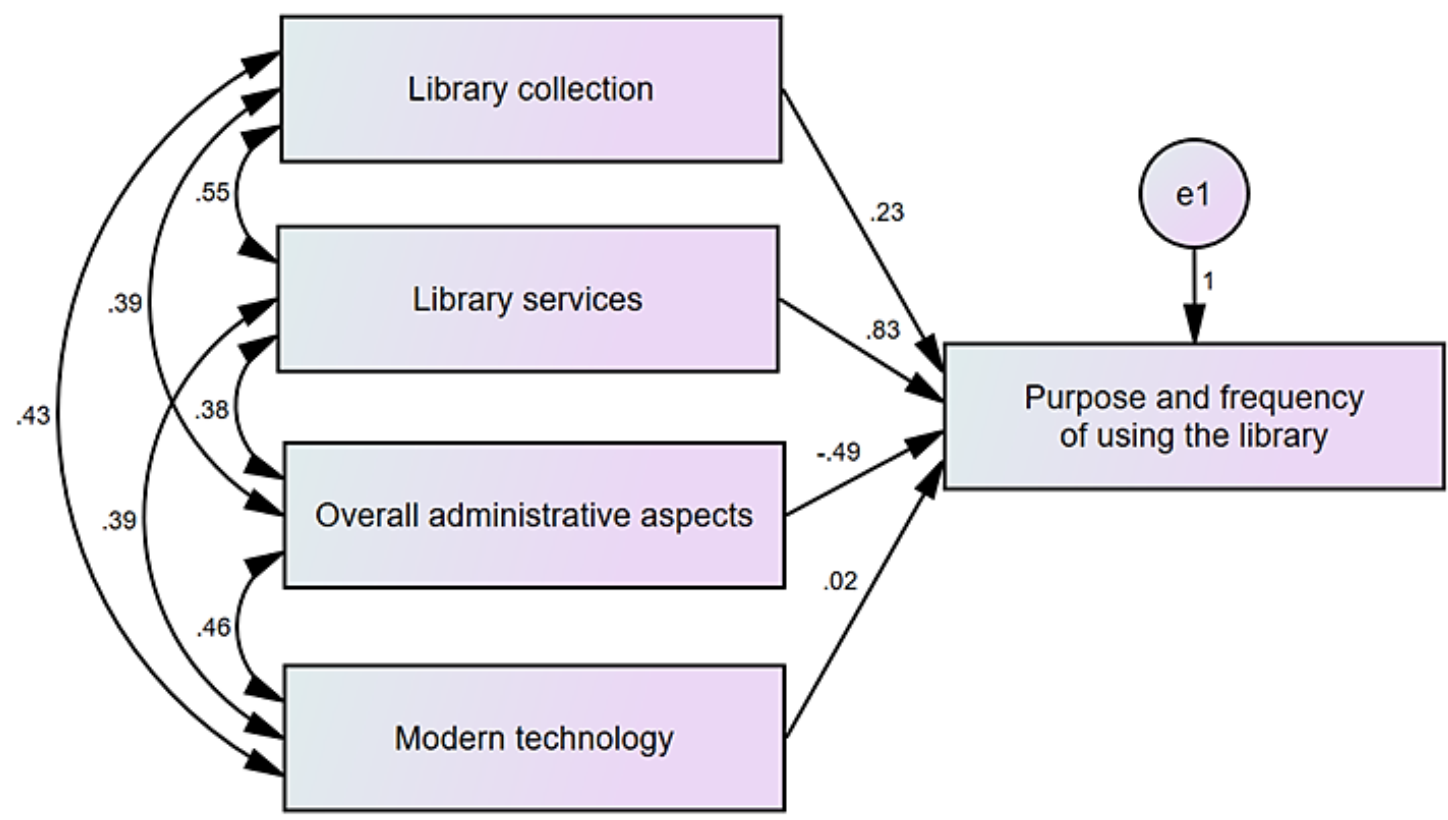

Figure 1: SEM model for the frequency of library usage

Table 8. Regression Weights

\begin{tabular}{|c|c|c|c|c|c|c|}
\hline Variables & & & Esti & & C.R & $\mathbf{P}$ \\
\hline $\begin{array}{l}\text { Purpose and frequency of } \\
\text { using the library }\end{array}$ & $<-$ & Library collection & .227 & 051 & $08^{4.4}$ & $*^{*}{ }^{*}$ \\
\hline $\begin{array}{l}\text { Purpose and frequency of } \\
\text { using the library }\end{array}$ & $<-$ & Library services & .825 & 049 & 710 & ${ }^{* *}{ }^{*}$ \\
\hline $\begin{array}{l}\text { Purpose and frequency of } \\
\text { using the library }\end{array}$ & $<-$ & $\begin{array}{c}\text { Overall } \\
\text { administrative aspects }\end{array}$ & -.491 & $041^{\circ}$ & 12.033 & ${ }^{* *}{ }^{*}$ \\
\hline $\begin{array}{l}\text { Purpose and frequency of } \\
\text { using the library }\end{array}$ & $<-$ & Modern technology & .015 & 071 & .21 & 830 \\
\hline
\end{tabular}

In the present study, the structural model of the exogenous latent variable is purpose and frequency of using the library with four variables namely library collection, library services, overall administrative aspects and modern technology. The primary measure of comparison, to demonstrate the value of the measurement error of the index negative factor loads more or less than 5. AMOS gives Standard Errors (SE) and Critical Ratios (CR) to assess the significance of each estimate. The critical ratios are what might as well be called standardordinary strays, and a value greater than 2.00 is viewed as significant $(Z= \pm 1.96$ is significant at the 0.05 level, twotailed). The Estimates are the partial relapse weights. If distributional presumptions are met, the C.R. ought to be 
$>2$ to be huge at 0.05 levels. Here, the C.R. estimations of larger part variables are more noteworthy than 2 for all the variables, which are considered to be highly significant except for modern technology. From the figure 1 and table 8 , it can be concluded that the model accepts that library services $(0.825)$ in purpose and frequency of using the libraryis the most influencing path in the SEM model, followed by library collection (0.227), and overall administrative aspects $(-0.491)$ in purpose and frequency of using the library.

Table 9. Model fit summary of Structural Equation Model

\begin{tabular}{|l|l|l|}
\hline Indices & Value & Suggested value \\
\hline NFI & 0.934 & $>0.90[28]$ \\
\hline CFI & 0.986 & $>0.90[29]$ \\
\hline
\end{tabular}

From table 9, the calculated Normed Fit Index (NFI) value shows 0.934 and Comparative Fit Index (CFI) value shows 0.986 . Both NFI and CFI are greater than 0.9 which represent the model is a good fit

\section{Discussion}

Traditional libraries, according to Vasishta [17], are 'closed-access' libraries due to a lack of current information and communication technologies (ICT). According to Vasishta [17], "keeping tradition for the sake of convenience can be counterproductive to progress; if we do not modernise, we will lose our competitive edge and will never be up to date." The establishment of an electronic library resource system in Delhi will thus encourage this process and enable researchers to make better use of existing resources. Weak library collections cause users to be dissatisfied with libraries [21,22,23,24].

To summarise, academic libraries play an enormous role in improving university students' accomplishments (in terms of their degree and research experience); however, electronic resources are more effective than borrowing facilities in today's academic libraries [25,10]. The implementation of effective digitization projects, which occurs in many university libraries around the world, is one of the important features of university libraries. These programmes support electronic data collection [26]. A desire shared by university students, staff, and administrators in Delhi is to have access to unlimited human knowledge (via digital services) without being hindered by distance. Although researchers in the Western world are studying how students use electronic services [27], students, teachers, and administrators in Delhi can only hope for such a vital service in their institutions. Realizing this dream for stakeholders is in the hands of policymakers, who play a critical role in meeting their needs.

\section{Conclusion}

This study provides a solid basis for future research into university libraries, which is desperately needed. Such research can include a variety of insights and suggestions for improving facility and service provision. The study's findings clearly show that university libraries in NCR Delhi, which are housed inside existing college buildings, contain obsolete resources that are randomly arranged, giving students and teachers negative attitudes toward libraries. There are no new collections or proper electronic systems in university libraries, which has created many difficulties for professors and students who conduct study in libraries. Today, students have taken digital access to collection and information to heart and use these tools to a large extent due to the search engine's simple interface. As a result, computerization could have a significant effect on students' willingness to return to libraries. Students' information needs have changed (and continue to change) as a result of the introduction and proliferation of electronic information, in which information content is made available to users for access and use. Due to these challenges, students and professors have stopped using libraries and existing services. The challenges faced by the abundance of information in the academic arena of the library would necessitate a more resourceful expansion of their collection and services in response to the needs of their patrons.

\section{References}

Majid,Shaheen and Abdoulaye,kaba"Use of the Internet for reference services in Malaysian Academic libraries" in "online information review" vol.24, no.5, 2000.

Gunasekera, C., 2010. Students Usage of an Academic Library: a user survey conducted at the Main Library University of Peradeniya. Journal of the University Librarians Association of Sri Lanka, 14(1), pp.43-60.

Weber, M. B. (2016). Editorial: Creativity and innovation. Library Resources \& Technical Services, 60(3), 138139.

Islam, M. A., Agarwal, N. K., \& Ikeda, M. (2017). Effect of knowledge management on service innovation in academic libraries. IFLA Journal, 43(3), 266-281.

King, D. L. (2018). Why stay on top of technology trends? Chapter 1. In D. L. King (Ed.). How to stay on top of emerging technology trends for libraries (pp. 6-13). USA: Library Technology Reports, Chicago. 
Raju, J. (2014). Knowledge and skills for the digital era academic library. The Journal of Academic Librarianship, 40, 163-170.

Gorham, U., \&Bertot, J. C. (2018). Social innovation in public libraries: Solving community challenges. The Library Quarterly, 88(3), 203-207.

Copeland, L. (2006). There be dragons ... Learning management and library systems in Canada. IFLA Journal, 32(3), 200-208.

Oliveira S.M. (2016). Space Preference at James White Library: What Students Really Want. The Journal of Academic Librarianship. 42. 10.1016/j.acalib.2016.05.009.

Montenegro, M., Clasing, P., Kelly, N., Gonzalez, C., Jara, M., Alarcon, R., Saurina, E. (2016). Library resources and students' learning outcomes: Do all the resources have the same impact on learning? The Journal of Academic Librarianship, 42(5), 551-556.

Cunningham, M., \& Walton, G. (2016). Informal learning spaces (ILS) in university libraries and their campuses: A Loughborough University case study. New Library World, 117(1/2), 49-62.

Holder, S., \& Lange, J. (2014). Looking and listening: A mixed-methods study of pace use and user satisfaction. Evidence Based Library and Information Practice, 9(3), 4-27.

Pierard, C., \& Lee, N. (2011). Studying space: Improving space planning with user studies. Journal of Access Services, 8(4), 190-207.

Storey, C. (2015). Commons consent: Librarians, architects and community culture in cocreating academic library learning spaces. Library Management, 36(8/9), 570-583.

Tavaniemi, J., Poutanen, J., \&Lahdemaki, R. (2015). Library as partner in co-designing learning spaces: A case study at Tampere University of Technology, Finland. New Review of Academic Librarianship, 21(3), 304324.

Adekanye, E. A. (2010). Computerization of the FatiuAdomolaAkesode library, Lagos State University. Information Development, 26(3), 237-244.

Vasishta, S. (2008). Modernization of library and information services in technical higher education institutions in north India: State-of-the-art report. IFLA Journal, 34(3), 286-294.

Wilders, C. (2017). Predicting the role of library bookshelves in 2025. The Journal of Academic Librarianship, 43, 384-391.

Perry \& Brownlow, Charlotte \&Mcmurray, Isabella \& Cozens, Bob. (2004). spss Explained. pp. 363-364.

Sureshchandar, G. S., Rajendran, C., \&Anantharaman, R. N. (2002). Determinants of customerperceived service quality: a confirmatory factor analysis approach. Journal of services Marketing, 16(1), 9-34.

Muthanna, A. (2011). Exploring the beliefs of teacher educators, students, and administrators: A case study of the English language teacher education program in Yemen. (Master's thesis. Retrieved from METU Library E-Thesis Archive).

Muthanna, A., \&Karaman, A. C. (2011). The need for change in teacher education in Yemen: The beliefs of prospective language teachers. Procedia-Social and Behavioral Sciences, 12, 224-232.

Muthanna, A., \&Karaman, A. C. (2014). Higher education challenges in Yemen: Discourses on English teacher education. International Journal of Educational Development, 37, 40-47.

Shiryan, A. (2009). An analysis of the current status of Sana'a University. The University Researcher Journal of Ibb University, 23, 199-238.

Hosono, K. (2006). Changes in university and public libraries in Japan. IFLA Journal, 32(2), 119-130.

Kanevskij, B. P. (1977). IFLA and certain problems of library theory. IFLA Journal, 3(3), 257-262.

Buhler, A., \&Cataldo, T. (2016). Identifying E-resources: An exploratory study of university students. Library Resources \& Technical Services, 60(1), 23-37.

Hu, L. T., \&Bentler, P. M. (1999). Cutoff criteria for fit indexes in covariance structure analysis: Conventional criteria versus new alternatives. Structural equation modeling: a multidisciplinary journal, 6(1), 1-55.

Hooper, D., Coughlan, J., \& Mullen, M. (2008). Structural equation modelling: Guidelines for determining model fit. Articles, 2 .. 